\title{
Language Learning Strategies and Beliefs about Language Learning in High-School Students and Students Attending English Institutes: Are They Different?
}

\author{
Fateme Saeb ${ }^{1} \&$ Elham Zamani ${ }^{1}$ \\ ${ }^{1}$ English Department, Faculty of Humanities, Shahid Rajaee Teacher Training University, Tehran, Iran \\ Correspondence: Fateme Saeb, English Department, Faculty of Humanities, Shahid Rajaee Teacher Training \\ University, Tehran, Iran. Tel: 98-091-5664-8549. E-mail: f.saeb1384@gmail.com
}

Received: September 10, 2013 Accepted: October 15, 2013 Online Published: November 5, 2013

doi:10.5539/elt.v6n12p79 URL: http://dx.doi.org/10.5539/elt.v6n12p79

\begin{abstract}
This paper reports a comparative study exploring language learning strategy use and beliefs about language learning of high-school students and students attending English institutes. Oxford's (1990) strategy inventory for language learning (SILL) and Horwitz's (1987) beliefs about language learning inventory (BALLI), were used to collect data. One-way multivariate analysis of variance was used to analyze the data. The results revealed significant differences between the two groups regarding their strategy use and beliefs about language learning. Institute students used significantly more memory, cognitive, compensation, metacognitive and social strategies. Also they held stronger beliefs about the difficulty of language learning and motivation and expectation than their peers in high school. The conclusions of the study along with related pedagogical implications are also discussed.
\end{abstract}

Keywords: language learning, language learning strategies, beliefs about language learning, high school students, English institute students

\section{Introduction}

Since the mid 1980s, an increasing interest in the role of individual learners' in language learning led researchers to explore learner variables as a method of analyzing diversities in students' command in learning a foreign or second language. Learners' use of learning strategies and their beliefs about language learning are among these variables which have been explored and investigated as heated topics in the realm of second language acquisition. Some studies have shown that students' perceptions, beliefs and attitudes are important contributive factors in the learning process and in the final achievement (Breen, 2001). For instance, second/foreign language learners may have firm beliefs and opinions about the nature and the process of the language learning, its difficulty, the efficacy of learning strategies, their own assumptions about success and teaching approaches. Horwitz (1987, 1988) found that prior exposure to language learning situations along with cultural backgrounds can influence learners' beliefs about language learning. Also, the possible relationship between the learners' beliefs about language learning and their choice of learning strategies has been suggested in some studies (Abraham \& Vann, 1987; Horwitz, 1987, 1988; Chang and Shen, 2005; Yang, 1999). According to Hong (2006), investigating students' beliefs and their relationship with more specific areas such as language learning strategies, can provide us with valuable sources of insight into the language learning process.

Learners' beliefs about the nature and process of language and learning and the use of learning strategies have been investigated and studied by some Iranian researchers in recent years (Fazeli, 2011; Nikoopour \& Farsani, 2010; Pishghadam \& Pourali, 2011; Dehghan Harati, 2011; Yamini \& Dehghan, 2005). However, very few studies have compared different proficiency groups in terms of their language learning strategies and beliefs (Ghavamnia et al., 2011; Abedini et al., 2011; Yamini \& Dehghan, 2005). English language learning and teaching in Iran has a special status: although English is a compulsory subject from the first grade in junior high school and the students study English for at least two hours a week during seven years, many of them lack basic communicative abilities at the end of their education in senior high school. Their limited proficiency in English which is mostly due to a dominance of the grammar-translation method in high schools (Dolati \& Seliman, 2011) also negatively affects their performance in English courses in university. Some students, however, have the chance of attending 
English institutes outside the school. These are private, usually well-equipped schools for teaching English which are, for the most part, concentrated on teaching listening and speaking skills through more scientific and modern methodologies. Students attending these institutes often have a better command in the classes of high school and are outstandingly more proficient, more successful language learners compared to their peers who do not attend English institutes. Seeking solutions for problems of this sort, Chamot (2004) believes that an important reason supporting research into language learning strategies is that less successful language learners can be taught new strategies, and become better language learners. Therefore, in order to improve language instruction in high school to an efficacy level comparable to that of the English institutes, an understanding of the two groups' language learning strategies and beliefs seems necessary. As Horwitz (1999) asserted, an integral part of appreciating learner strategies and devising effective language instruction is identifying learner beliefs about language learning; nevertheless, so far there has been no investigation of how these beliefs and strategies may vary across public high-school students and private English institutes. Thus, the aim of the present study is to start compensating for this lack of research attempt, by examining the difference between language learning strategies and beliefs of high-school students and students attending English institutes.

\section{Review of the Literature}

\subsection{Learners' Beliefs about Language Learning}

Language learning beliefs have been defined in the literature as "general assumptions that students hold about themselves as learners, about factors influencing language learning, and about the nature of language learning and teaching" (Victori \& Lockhart, 1995, p. 224). Beliefs about language learning are regarded as a constituent of metacognitive knowledge, which involve the conceptions that individuals hold about themselves as language learners, inclusive of their objectives and demands (Flavell, 1987; cited in Bernat \& Gvozdenko, 2005). Barcelos (2000; cited in Aragao, 2011) suggested that language teachers should take account of their students' beliefs as tools the students use in understanding their learning context and in dealing with it. Horwitz (1999) also deemed it critical to be conscious about learner beliefs in order to better appreciate their approaches to language learning, and their practice of learning strategies to improve language education.

So far, belief studies have been mostly concentrated on English language learners' beliefs using BALLI as the instrument in different ESL and EFL contexts. These studies have investigated the link between beliefs and gender (Bernat and Lloyd, 2007; Tercanlioglu, 2005; Siebert, 2003), language proficiency (Abedini et al., 2011), language learning strategies (Yang, 1999), the effect of culture on beliefs (Horwitz, 1999), and the latent aspects of language learners' beliefs (Sakui \& Gaines, 1999).

Regarding the effect of proficiency level on learners' beliefs, the findings of some studies have revealed a link between beliefs and proficiency and that they differ in more and less proficient learners (Samimy \& Lee, 1997; cited in Manzanaresis \& Murphy, 2010; Oxford \& Ehrman, 1995; White, 1999; Abedini et al., 2011). Oxford \& Ehrman's study of learner variables and proficiency ratings found a relationship between beliefs and ability to learn languages and proficiency in both speaking and reading. Samimy and Lee (1997) also conducted a study of EFL Chinese learners in which they correlated learner beliefs with proficiency. They found that learners with higher grades had more confidence in their ability to learn foreign languages and were more willing to practice with native speakers. Along the same line, Abedini et al. (2011) discovered a significant positive correlation between belief and language proficiency. EFL learners who possessed more constructive and plausible beliefs typically had higher level language proficiency.

\subsection{Language Learning Strategies}

Oxford (1990) defined language learning strategies as “... specific actions, behaviors, steps or techniques that students use to improve their progress in developing L2 skills. These strategies can facilitate the internalization, storage, retrieval or use of the new language" (p. 8). Different classification systems have made the effort to classify single strategies in broader categories. The most repetitively cited and comprehensive classification of learning strategies hitherto, is that of Oxford (1990) who developed the Strategy Inventory for Language Learning (SILL).

Oxford (1990) drew a general distinction between direct and indirect strategies, which are broken down into 6 groups: memory strategies, cognitive strategies, compensation strategies, metacognitive strategies, affective strategies, and social strategies. Direct strategies encompass "strategies that directly involve the target language" meaning that they "require mental processing of the language" (1990:37). whereas the indirect strategies "provide indirect support for language learning through focusing, planning, evaluating, seeking opportunities, controlling anxiety, increasing cooperation and empathy and other means" (1990:151). Oxford's classification was used as a framework for this study because of its systematicity and comprehensiveness. 
Studies of language learning strategies, so far, have investigated the ways in which the selection of learning strategies is influenced by diverse factors like gender (Oxford \& Burry-Stock, 1995; Yilmaz, 2010), age (Purdie \& Oliver, 1999; Chesterfield \& Chesterfield, 1985), second language proficiency (Liu, 2004), academic specialization (Peacock \& Ho, 2003), bilingualism/monolingualism (Hong-Nam \& Leavell, 2007), cultural background (Oxford, 1996), motivation (Schmidt \& Watanabe, 2001), and beliefs about language learning (Hong, 2006; Yang, 1999, Chang \& Shen, 2005).

Many studies have been conducted investigating the correlation between strategy use and language proficiency in most of which a strong relationship was found between the two variables (Su, 2005; Griffiths, 2003; Wharton, 2000; Yang, 2010; Peacock \& Ho, 2003). Su (2005) arrived at a meaningful difference in strategy use by self-evaluated English language proficiency which established a linear correlation between learning strategies and levels of self-rating proficiency. The results of Peacock and Ho (2003) and Abu Radwan (2008) also made it clear that higher proficiency learners habitually exercised more cognitive and metacognitive strategies. In another study, Yamini and Dehghan (2005) investigated the relationship between strategies, beliefs and proficiency level. The results revealed a significant relation between the proficiency level and the use of cognitive, compensation, and metacognitive strategies. Besides, more proficient students expressed negative views about traditional ways of language learning like memorization and learning grammar rules.

\section{Research Questions}

This study was conducted to answer the following questions: 1) Do high-school students differ in their use of language learning strategies from students attending English institutes? 2) Are high-school students' beliefs about language learning different from those of students attending English institutes?

\section{The Study}

\subsection{Participants}

Two hundred and sixty-two high-school students from different cities in Iran participated in this study. One-hundred and fifty-two students were female and one-hundred and ten students comprised the male group. One hundred and twenty-seven students were attending English institutes outside the school and one hundred and thirty-five were studying English only in the public high-school classes. Their age ranged from 14 to 18 years. The sample included students of the first to the fourth grade in high school. The high-school students' proficiency level ranged from beginner to lower-intermediate, and the institute students ranged from lower to upper intermediate.

\subsection{Instrumentation}

The instruments in this study were two questionnaires: the Strategy Inventory for Language Learning (SILL, ESL/EFL 7.0 version) developed by Oxford (1990), and the Beliefs about Language Learning Inventory (BALLI, ESL/EFL version) developed by Horwitz (1987). Both questionnaires were translated into Persian, pilot tested and modified for the study. A few questions regarding demographic information were also added.

The BALLI assesses learners' beliefs within five factors: the difficulty of language learning, foreign language aptitude, the nature of language learning, learning and communication strategies, and motivation and expectations. Items are scored on a five-point Likert scale: $1=$ strongly disagree, $2=$ disagree, $3=$ neither agree nor disagree, $4=$ agree, $5=$ strongly agree. Cronbach alpha reliability for the translated version was found to be .66 .

The SILL is divided into six categories of strategies: memory- storing and retrieving information (9 items), cognitive- understanding and producing the language (14 items), compensation- overcoming limitations in language learning (6 items), metacognitive- centering and directing learning (9 items), affective- controlling emotions, motivation (6 items), and social-cooperating with others in language learning (6 items). It employs a five-point Likert-scale: $1=$ never or almost never true of me, $2=$ generally not true of me, $3=$ somewhat true of me, $4=$ generally true of me, and $5=$ always or almost always true of me. The Cronbach alpha for the Persian version of the SILL was estimated to be .91 .

\subsection{Data Collection and Analysis}

The questionnaires were administered during the students' regular class time by their English teachers. Before the administration procedure, a brief explanation on the purpose of the study was given to the students. The gathered data were analyzed using SPSS version 18.0. Descriptive statistics, including means and standard deviations, were computed to summarize the students' responses to the SILL and BALLI items. To identify the significance of the difference between beliefs and strategy factors of high-school students and students attending 
English institutes, a one-way between groups multivariate analysis of variance was conducted.

\section{Results}

\subsection{Differences in Strategy Use}

To answer the first research question concerning the difference between the two groups' strategy use, the data were submitted to a one-way multivariate analysis of variance (MANOVA). The six factors of the SILL were used as the dependent variables and the type of school was used as the independent variable. There was a statistically significant difference between high-school students and students attending English institutes regarding their use of language learning strategies, $F(6,257)=7.25, P=.000$; Wilks' Lambda $=.85$; partial eta squared $=.14$. The results for each dependent variable were also considered separately (Table 1 ).

Table 1. One-way MANOVA for the effect of school type on the six strategy factors

\begin{tabular}{lllllll}
\hline Dependent Variable & $\begin{array}{l}\text { Type III Sum } \\
\text { of Squares }\end{array}$ & df & $\begin{array}{l}\text { Mean } \\
\text { Square }\end{array}$ & F & Sig. & $\begin{array}{l}\text { Partial Eta } \\
\text { Squared }\end{array}$ \\
\hline Memory & 598.476 & 1 & 598.476 & 16.956 & .000 & .061 \\
Cognitive & 2479.679 & 1 & 2479.679 & 37.885 & .000 & .126 \\
Compensation & 147.623 & 1 & 147.623 & 8.554 & .004 & .032 \\
Metacognitive & 1145.099 & 1 & 1145.099 & 21.763 & .000 & .077 \\
Affective & 3.831 & 1 & 3.831 & .181 & .671 & .001 \\
Social & 242.148 & 1 & 242.148 & 14.021 & .000 & .051 \\
\hline
\end{tabular}

As shown in Table 1, the difference of five strategy factors including memory, cognitive, compensation, metacognitive and social strategies, reached statistical significance, using a Bonferroni adjusted alpha level of .008. The only factor which was not significantly different between the two groups was the factor of affective strategies. An investigation of mean scores of the two groups in the six strategy factors (Table 2) indicated that students attending English institutes used more strategies than their peers in high school.

Table 2. Mean scores of high-school and institute students in the six strategy factors

\begin{tabular}{llllll}
\hline $\begin{array}{l}\text { Dependent } \\
\text { Variable }\end{array}$ & \multirow{2}{*}{ School } & Mean & \multirow{2}{*}{ Std. Error } & \multicolumn{2}{c}{ 95\% Confidence Interval } \\
\cline { 5 - 6 } & & & .511 & 24.252 & 26.266 \\
S1 memory & public school & 25.259 & .523 & 27.241 & 29.301 \\
& Institute & 28.271 & .696 & 37.281 & 40.023 \\
S2 cognitive & public school & 38.652 & .712 & 43.380 & 46.186 \\
& institute & 44.783 & .358 & 15.459 & 16.867 \\
S3 compensation & public school & 16.163 & .366 & 16.939 & 18.379 \\
& Institute & 17.659 & .624 & 28.348 & 30.807 \\
S4 metacognitive & public school & 29.578 & .639 & 32.487 & 35.002 \\
& Institute & 33.744 & .396 & 15.902 & 17.461 \\
S5 affective & public school & 16.681 & .405 & 16.125 & 17.720 \\
& Institute & 16.922 & .358 & 14.155 & 15.564 \\
S6 social & public school & 14.859 & .366 & 16.055 & 17.496 \\
& Institute & 16.775 & & & Upper Bound \\
\hline
\end{tabular}

\subsection{Differences in Language Learning Beliefs}

To examine whether attending English institutes has any effect on the students' beliefs about language learning, a one-way multivariate analysis of variance (MANOVA) was done. The five belief factors and the type of school 
were used as the dependent and the independent variables respectively. The MANOVA results revealed a statistically significant difference between high-school students and students attending English institutes in terms of their beliefs about language learning, $F(5,256)=7.02, P=.000$; Wilks' Lambda $=.87$; partial eta squared $=.12$. The results for each of the five belief factors were also obtained separately (Table 3 ).

Table 3. One-way MANOVA for the effect of school type on the five belief factors

\begin{tabular}{lllllll}
\hline $\begin{array}{l}\text { Dependent } \\
\text { Variable }\end{array}$ & $\begin{array}{l}\text { Type III Sum } \\
\text { of Squares }\end{array}$ & df & $\begin{array}{l}\text { Mean } \\
\text { Square }\end{array}$ & F & Sig. & $\begin{array}{l}\text { Partial Eta } \\
\text { Squared }\end{array}$ \\
\hline Aptitude & 9.127 & 1 & 9.127 & .582 & .446 & .002 \\
Difficulty & 69.902 & 1 & 69.902 & 18.249 & .000 & .066 \\
Nature & .931 & 1 & .931 & .075 & .784 & .000 \\
Strategy & 6.914 & 1 & 6.914 & .670 & .414 & .003 \\
Motivation & 103.509 & 1 & 103.509 & 13.097 & .000 & .048 \\
\hline
\end{tabular}

As seen in Table 3, the difference of two belief factors including beliefs about the difficulty of language learning, and motivation and expectations was statistically significant, using a Bonferroni adjusted alpha level of .01 . The factors of beliefs about foreign language aptitude, the nature of language learning, and learning and communication strategies were not significantly different between the two groups. An examination of mean scores of the two groups in the five belief factors (Table 4) revealed higher means of institute students in the factors of motivation and language learning difficulty.

Table 4. Mean scores of high-school and institute students in the five belief factors

\begin{tabular}{llllll}
\hline \multirow{2}{*}{$\begin{array}{l}\text { Dependent } \\
\text { Variable }\end{array}$} & \multirow{2}{*}{ School } & \multirow{2}{*}{ Mean } & Std. Error & \multicolumn{2}{l}{$95 \%$ Confidence Interval } \\
\cline { 5 - 6 } & & & & Lower Bound & Upper Bound \\
\hline Aptitude & Public school & 31.696 & .341 & 31.025 & 32.368 \\
& Institute & 31.323 & .351 & 30.631 & 32.015 \\
Difficulty & Public school & 10.407 & .168 & 10.076 & 10.739 \\
& Institute & 11.441 & .174 & 11.099 & 11.783 \\
Nature & Public school & 26.519 & .303 & 25.921 & 27.116 \\
& Institute & 26.638 & .313 & 26.022 & 27.254 \\
Strategy & Public school & 26.785 & .276 & 26.241 & 27.330 \\
& Institute & 27.110 & .285 & 26.549 & 27.672 \\
Motivation & Public school & 20.341 & .242 & 19.864 & 20.817 \\
& Institute & 21.598 & .249 & 21.107 & 22.090 \\
\hline
\end{tabular}

\section{Discussion and Conclusions}

The data analysis revealed a number of significant findings. Regarding language learning strategy use, it was found that students attending English institutes used significantly more memory, cognitive, compensation, metacognitive and social strategies. The most significant difference between the two groups was in the cognitive strategies followed by metacognitive and memory strategies. This result is consistent with the findings of previous studies (Peacock \& Ho, 2003; Abu Radwan, 2008; Yamini \& Dehghan, 2005) in which more proficient learners were found to use more cognitive, matacognitive and memory strategies. The reasons for this difference in students' use of strategies might be sought in the difference of the teaching methodologies and teaching materials in high school and in institutes. The high-school textbooks were written more than two decades ago and are used almost unchanged till now. Naturally they reflect teaching approaches and principles of the past, and they don't have the potentials of strategy-based instruction which might have a contribution in high-school students' different pattern of using strategies. 
The difference of the two groups was not statistically significant in affective strategies where high school and institute students had very close mean scores. A possible explanation for this result can be sought in the cultural background of the students. Affective strategies refer to learners' emotions, attitudes, motivation and values toward learning language (Oxford,1990) and some affective strategies require expressing one's feelings, however, there is a reluctance among Iranians to communicate their feelings and emotions, a trait common in eastern cultures (Gudykunst et al., 1996).

In language learning beliefs part, the differences between the two groups were significant only with regard to beliefs about the difficulty of language learning, and motivation and expectations, where institute students held stronger and more positive beliefs than high-school students. This means that institute students were more motivated to learn English and possessed a more sophisticated concept of language learning difficulty. This result is in agreement with the results of Samimy and Lee (1997) and Yamini and Dehghan (2005).

Putting all things together, as institute students in this study were found to have higher motivation to learn English, it seems logical to conclude that their higher level of motivation led them to more conscious engagement in the process of language learning, and along with their higher level of proficiency, made them more aware of their language learning needs, thus they resorted to employing language learning strategies more than their peers in high school did. The association between language learning motivation and the strategy factors has been investigated and confirmed in previous studies (Yang, 1999; Chang and Shen, 2005; Abedini et al., 2011; Saeb, 2012).

The results of the present study demonstrated that attending English institutes outside the school had a main effect on the students' learning strategy use and their beliefs about language learning. As Chamot (2004) believed one of the major reasons encouraging research into language learning strategies is that less successful language learners can be trained new strategies, and become more efficient language learners, it is suggested that future research in this area focus on detecting the possible unique features of language instruction that institute students receive and the successful students' characteristics in order to improve language instruction in public high schools through applying these features, fostering positive beliefs about language learning, and introducing strategy-based instruction.

\section{References}

Abedini, A., Rahimi, A., \& Zare-ee, A. (2011). Relationship between Iranian EFL learners' beliefs about language learning, their language learning strategy use and their language proficiency. Procedia Social and Behavioral Sciences, 28, 1029-1033. http://dx.doi.org/10.1016/j.sbspro.2011.11.188

Abu Radwan, A. (2008). Effects of L2 proficiency and gender on choice of language learning strategies by university students majoring in English. Asian EFL Journal, 19, 25-38.

Aragao, R. (2011). Beliefs and emotions in foreign language learning. System, 39, 302-313. http://dx.doi.org/10.1016/j.system.2011.07.003

Bernat, E., \& Gvozdenko, I. (2005). Beliefs about language learning: Current knowledge, pedagogical implications, and new research directions. TESL-EJ, 9. Retrieved from http://www-writing.berkeley.edu/TESL-EJ/ej33/a1.html

Bernat, E., \& Lloyd, R. (2007). Exploring the Gender Effect on EFL Learners' Beliefs about Language Learning. Australian Journal of Educational \& Developmental Psychology, 7, 79-91.

Breen, M. P. (Ed.) (2001). Learner contributions to language learning: New directions in research. Harlow, Essex: Pearson Education Limited.

Chamot, A. U. (2004). Issues in language learning strategy research and teaching. Electronic Journal of Foreign Language Teaching, 1, 14-26.

Chang, C., \& Shen, M. (2005). The effects of beliefs about language learning and learning strategy use of junior high school EFL learners in remote districts. Research in Higher Education Journal. Retrieved March, 2012, from www.aabri.com/manuscripts/10462.pdf

Chesterfield, R., \& Chesterfield, K. B. (1985). Natural order in children's use of second language learning strategies. Applied Linguistics, 6, 45-59. http://dx.doi.org/10.1093/applin/6.1.45

Dehghan Harati, R. (2011). Learners' beliefs, teachers' beliefs: Are they different? Iranian EFL Journal, 7 , 190-221.

Dolati, R., \& Seliman, S. (2011). An investigation of Iranian students' weaknesses in spoken English. Journal of 
Edupres, 1, 94-99.

Fazeli, S. H. (2011). The exploring nature of language learning strategies (LLSs) and their relationship with various variables with focus on personality traits in the current studies of second/foreign language learning. Theory and Practice in Language Studies, 1, 1311-1320. http://dx.doi.org/10.4304/tpls.1.10.1311-1320

Ghavamnia, M., Kassaian, Z., \& Dabaghi, A. (2011). The relationship between language learning strategies, language learning beliefs, motivation, and proficiency: A study of EFL learners in Iran. Journal of Language Teaching and Research, 2, 1156-1161. http://dx.doi.org/10.4304/jltr.2.5.1156-1161

Griffiths, C. (2003). Patterns of language learning strategy use. System, 31, $367-383$. http://dx.doi.org/10.1016/S0346-251X(03)00048-4

Gudykunst, W. B., Ting-Toomey, S., \& Nishida, T. (1996). Communication in Personal Relationships across Cultures. SAGE Publications.

Hong-Nam, K., \& Leavell, A. G. (2006). Language learning strategy use of ESL students in an intensive English learning context. System, 34, 399-415. http://dx.doi.org/10.1016/j.system.2006.02.002

Hong, K. (2006). Beliefs about Language Learning and Language Learning Strategy Use in an EFL Context: A Comparison Study of Korean and Bilingual Korean-Chinese University Students. Dissertation abstracts international, 67(04), 1272.

Horwitz, E. K. (1999). Cultural and situational influences on foreign language learners' beliefs about language learning: A review of BALLI studies. System, $27, \quad 557-576$. http://dx.doi.org/10.1016/S0346-251X(99)00050-0

Horwitz, E. K. (1987). Surveying student beliefs about language teaming. In A. L. Wenden, \& J. Robin (Eds.), Learner strategies in language learning (pp. 119-132). London: Prentice Hall.

Horwitz, E. K. (1988). The beliefs about language learning of beginning foreign language students. Modern Language Journal, 72, 283-294. http://dx.doi.org/10.1111/j.1540-4781.1988.tb04190.x

Hosenfeld, C. (1978). Learning about learning: Discovering our students'strategies. Foreign Language Annals, 9 , 117-129. http://dx.doi.org/10.1111/j.1944-9720.1976.tb02637.x

Liu, D. (2004). EFL proficiency, gender and language learning strategy use among a group of Chinese technological institute English majors. Annual Review of Education, Communication and Language Sciences, 1, 36-56.

Nikoopour, J., \& Amini Farsani M. (2010). On the Relationship between Language Learning Strategies and Cognitive Styles among Iranian EFL Learners. Journal of English Studies, 1, 81-101.

Oxford, R. L. (1990). Language learning strategies: What every teacher should know. Boston: Heinle \& Heinle.

Oxford, R. L., \& Burry-Stock, J. (1995). Assessing the use of language learning strategies worldwide with the $\mathrm{ESL} / \mathrm{EFL}$ version of the strategy inventory of language learning (SILL). System, 23, 1-23. http://dx.doi.org/10.1016/0346-251X(94)00047-A

Oxford, R. L. (1996). Employing a Questionnaire to Assess the Use of Language Learning Strategies. Applied Language Learning, 7, 25-45.

Oxford, R. L., \& Ehrman, M. E. (1995). Adults' language learning strategies in an intensive foreign language program in the United States. System, 23, 359-386. http://dx.doi.org/10.1016/0346-251X(95)00023-D

Peacock, M., \& Ho, B. (2003). Student language learning strategies across eight disciplines. International Journal of Applied Linguistics, 13, 179-200. http://dx.doi.org/10.1111/1473-4192.00043

Pishghadam, R., \& Pourali, S. (2011). Iranian PhD students' beliefs about language learning and teaching: A qualitative study. World Journal of Education, 1, 63-71. http://dx.doi.org/10.5430/wje.v1n1p63

Purdie, N., \& Oliver, R. (1999). Language learning strategies used by bilingual school-aged children. System, 27, 375-388. http://dx.doi.org/10.1016/S0346-251X(99)00032-9

Rodriguez Manzanaresis, M. A., \& Murphy, E. (2010). The Language Learning Beliefs of Self-identified, Successful Learners of Spanish as a Foreign Language. Canadian and International Education, 39, 75-89.

Saeb, F. (2012). The relationship between high-school students' beliefs about language learning and their use of learning strategies. Unpublished MA thesis, Shahid Rajaii University, Tehran, Iran.

Sakui, K., \& Gaies, S. J. (1999). Investigating Japanese learners' beliefs about language learning. [Special Issue]. 
System, 27, 473-492. http://dx.doi.org/10.1016/S0346-251X(99)00046-9

Siebert, L. L. (2003). Student and teacher beliefs about language learning. The ORTESOL Journal, 21, 7-39.

Schmidt, R., \& Watanabe, Y. (2001). Motivation, Strategy Use, and Pedagogical Preferences in Foreign Language Learning. In Z. Dornyei, \& R. Schmidt (Eds.), Motivation and Second Language Acquisition (pp. 313-359). Honolulu, HI: Second Language Teaching and Curriculum Center. PMid: 11529849.

$\mathrm{Su}$, M. M. (2005). A study of EFL technological and vocational college students' language learning strategies and their self-perceived English proficiency. Electronic Journal of Foreign Language Teaching, 2, 44-56.

Tercanlioglu, L. (2004). Exploring gender effect on adult foreign language learning strategies. Issues in Educational Research, 14, 181-193.

Victori, M., \& Lockhart, W. (1995). Enhancing metacognition in self-directed language learning. System, 23, 223-234. http://dx.doi.org/10.1016/0346-251X(95)00010-H

Wenden, A. (1987). How to be a successful language learner: Insights and prescriptions from L2 learners. In A. Wenden, \& J. Rubin (Eds.), Learner strategies in language learning (pp. 103-117). London: Prentice Hall.

Wharton, G. (2000). Language learning strategy use of bilingual foreign language learners in Singapore. Language Learning, 50, 203-243. http://dx.doi.org/10.1111/0023-8333.00117

White, C. (1999). Expectations and emergent beliefs of self-instructed language learners. System, 27, 443-457. http://dx.doi.org/10.1016/S0346-251X(99)00044-5

Yamini, M., \& Dehghan, F. (2005). Relationship between foreign language beliefs, proficiency level and the use of language strategies (case study: Female English majors in Shiraz). Journal of Humanities, 15, 123-149.

Yang, N. D. (1999). The relationship between EFL learners' beliefs and learning strategy use. System, 27 , 515-535. http://dx.doi.org/10.1016/S0346-251X(99)00048-2

Yang, M. (2010). Language learning strategies of English as foreign language university students in Korea. Unpublished doctoral dissertation. Indiana State University, Terre Haute, Indiana.

Yilmaz, C. (2010). The relationship between language learning strategies, gender, proficiency and self-efficacy beliefs: A study of ELT learners in Turkey. Procedia Social and Behavioral Sciences, 2, 682-687. http://dx.doi.org/10.1016/j.sbspro.2010.03.084

\section{Copyrights}

Copyright for this article is retained by the author(s), with first publication rights granted to the journal.

This is an open-access article distributed under the terms and conditions of the Creative Commons Attribution license (http://creativecommons.org/licenses/by/3.0/). 